\title{
PEMBELAJARAN BERBASIS KONSTRUKTIVISME MENGGUNAKAN MEDIA ANIMASI DENGAN KERANGKA KERJA TPCK DAN GAYA BELAJAR TERHADAP PRESTASI BELAJAR SISWA
}

\author{
HANDY DARMAWAN \\ 08125792092 \\ brownjacket@ rocketmail.com \\ Program Studi Pendidikan Fisika, IKIP-PGRI Pontianak \\ Jln. Ampera No. 88 Pontianak
}

\begin{abstract}
Abstrak. Tujuan penelitian ini adalah untuk mengetahui pengaruh pembelajaran berbasis konstruktivisme menggunakan media animasi dengan kerangka kerja TPCK dan gaya belajar terhadap prestasi belajar siswa. Penelitian ini menggunakan metode eksperimen dengan rancangan true eksperimen. Populasi penelitian ini adalah seluruh siswa kelas XI SMK 1 Dedai tahun pelajaran 2014/2015 prodi teknologi komputer dan jaringan sejumlah 4 kelas. Sampel diambil dari populasi sejumlah 2 kelas. Teknik pengumpulan data yang digunakan pada penelitian ini adalah metode tes untuk mengukur prestasi belajar, angket untuk mengukur gaya belajar, dan lembar observasi untuk mengukur hasil belajar aspek afektif dan psikomotorik mahasiswa. Hasil penelitian menunjukkan; 1) profil gaya belajar siswa kelas XI SMK 1 Dedai; 2) terdapat pengaruh pembelajaran berbasis konstruktivisme menggunakan media animasi terhadap prestasi belajar siswa, (3) tidak terdapat pengaruh gaya belajar terhadap prestasi belajar siswa, (4) terdapat pengaruh penggunaan media animasi dan gaya belajar terhadap prestasi belajar siswa.
\end{abstract}

Kata kunci: Konstruktivisme, TPCK, Media Animasi, Gaya Belajar.

\begin{abstract}
The purpose of this study was to determine the influence of constructivism based learning using media animation with TPCK framework and learning styles on student achievement. This study used an experimental method with a true experimental design. The population of this research is all class XI student of SMK 1 Dedai the academic year 2014/2015 Prodi computer technology and network of four classes. Samples were taken from a population of 2 classes. Data collection techniques used in this study is the test method to measure student achievement, to measure learning style questionnaire and observation sheet as to measure learning outcomes affective and psychomotor student. The results showed; 1) learning style profiles of class XI student of SMK 1 Dedai; 2) there is influence of constructivism based learning using animation media on student achievement, (3) there is no influence of learning styles on student achievement, (4) there is the influence of animation media usage and learning styles on student achievement.
\end{abstract}

Keyword: Constructivism, TPCK, Animation Learning, Learning Style.

\section{PENDAHULUAN}

Kurikulum Pendidikan SMK (2009) menyatakan bahwa tujuan pendidikan SMK adalah meningkatkan kecerdasan, pengetahuan, kepribadian, akhlak mulia, serta ketekunan untuk hidup mandiri dan mengikuti pendidikan lebih lanjut sesuai dengan kejuruannya. Lulusan SMK diharapkan mempunyai skill atau keahlian dibidangnya masing-masing, sehingga siap pakai di dunia kerja. 
Pada hakikatnya, pendidikan merupakan kegiatan yang telah berlangsung seumur hidup manusia, artinya sejak adanya manusia telah terjadi usaha-usaha pendidikan dalam rangka memberikan kemampuan kepada subjek didik untuk dapat hidup dalam masyarakat dan lingkungannya. Langeveld (1971:21) mengatakan bahwa "Pendidikan adalah setiap usaha, pengaruh, perlindungan dan bantuan yang diberikan kepada anak didik yang bertujuan pada pendewasaan anak itu", sehingga dengan diberikannya pendidikan maka seseorang anak didik sanggup untuk berbuat dan bertindak sebagai situasi yang dapat menolong individu yang mengalami perubahan suatu proses, dengan demikian pendidikan dipandang penting sebagai pelaku perubahan dan perkembangan dalam masyarakat.

Berdasarkan teori tersebut dapat dikatakan bahwa peningkatan kualitas pendidikan peserta didik tidak terlepas dari proses penyelenggaraan pendidikan itu sendiri, dimana proses yang terjadi diharapkan peserta didik dapat mengkonstruk stimulus menjadi konsep-konsep yang dapat menjelaskan pemahaman sesuai dengan apa yang dipelajarinya dengan harapan peserta didik dapat berkembang sesuai dengan potensinya masingmasing.

Berdasarkan data dari Trends in International Mathematics and Science Study (TIMSS) tahun 2011 rata-rata prestasi MIPA (Matematika dan Ilmu Pengetahuan Alam) siswa Indonesia adalah 386 atau urutan ke-37 dari 42 negara sedangkan data Programe for International Assessment (PISA) tahun 2012 rata-rata prestasi MIPA (Matematika dan Ilmu Pengetahuan Alam) siswa Indonesia adalah 375 atau urutan ke-64 dari 65 negara. Data tersebut telah cukup untuk menunjukkan bahwa hasil prestasi belajar siswa Indonesia khususnya pada bidang Sains belum optimal seperti yang diharapkan. Pada dasarnya tujuan guru mengajar adalah untuk mengadakan perubahan yang dikehendaki dalam tingkah laku anak didik. Perubahan dilakukan seorang guru dengan menggunakan suatu strategi mengajar untuk mencapai tujuan dengan memilih metode pendekatan yang tepat. Upaya meningkatkan mutu pendidikan tidak hanya bergantung pada faktor guru saja, tetapi berbagai faktor lainnya juga berpengaruh untuk menghasilkan keluaran atau output proses pengajaran bermutu. Namun pada hakikatnya guru tetap merupakan kunci utama yang paling menentukan, sebab guru adalah salah satu unsur utama yang mempengaruhi dalam sistem pendidikan.

Titik tolak dari implementasi pembelajaran sains harus sejalan dengan hakekat pembelajaran sains itu sendiri, Carin dan Evans (dalam Sudarisman, 2010:239) menyatakan "Hakikat pembelajaran sains meliputi 4 hal yakni produk, proses, sikap dan teknologi", pernyataan Carin dan Evans disini dapat dijelaskan bahwa dimana sains sebagai produk, berarti dalam sains terdapat fakta, hukum, prinsip, dan teori-teori yang sudah diterima kebenarannya. Sains sebagai proses artinya suatu metode untuk mendapatkan pengetahuan. Sains sebagai sikap artinya dalam sains terkandung pengembangan sikap ilmiah. Sains sebagai teknologi artinya sains berkaitan erat dan digunakan dalam kehidupan sehari-hari. Pencapaian hakikat sains tidak luput dari penyelesaian masalah dalam proses pembelajaran yang menerapkan model yang sesuai dengan tujuan pembelajaran agar pemahaman mahasiswa terhadap materi tidak sekedar proses menghafal dan memahami tetapi juga dapat melakukan analisis, kajian, penemuan dan penerapan.

Berdasarkan observasi yang dilakukan, prestasi belajar untuk mata pelajaran Ilmu Pengetahuan Alam (IPA) siswa kelas XI SMK 1 Dedai masih jauh dari yang diharapkan. Belum optimalnya prestasi belajar tersebut dapat dilihat pada Tabel 1, dimana nilai ratarata siswa semua kelas masih di bawah 7 (KKM yang ditetapkan kelas XI SMK 1 Dedai). 
Tabel 1. Rerata Nilai Siswa

\begin{tabular}{cccc}
\hline No & Kelas & KKM & Nilai Rata-Rata \\
\hline 1 & XI P1 & 7,00 & 6,03 \\
2 & XI P2 & 7,00 & 5,87 \\
3 & XI P3 & 7,00 & 5,60 \\
4 & XI P4 & 7,00 & 6,13 \\
\hline \multicolumn{3}{c}{ Sumber: hasil rata-rata nilai siswa, Juli 2013. }
\end{tabular}

Analisa sementara rendahnya nilai mata pelajaran IPA siswa dikarenakan siswa kurang aktif dalam menggali informasi terkait materi IPA yang diajarkan oleh guru, dominasi guru masih lebih besar dibandingkan keaktifan siswa dalam pembelajaran, metode ceramah dan tugas yang diberikan belum sepenuhnya dapat mengatasi kesulitan siswa. Kemampuan pemahaman siswa dalam menerima materi pelajaran IPA perlu ditingkatkan dan keaktifan siswa dalam mengeluarkan pendapat perlu dilatih sesuai dengan kemampuan kognitifnya.

Selain itu, berdasarkan pengamatan dan wawancara terhadap guru dan siswa, hal tersebut terindikasi bahwa siswa sulit dalam memahami konsep pelajaran pada saat dilakukannya penyampaian teori dikarenakan keterbatasan alat peraga untuk mengilustrasikan materi yang tidak dapat diamati secara langsung. Di SMK 1 Dedai memiliki ruang multimedia yang lengkap dan belum dilengkapi dengan fasilitas wifi, sekolah ini juga menyediakan LCD proyektor meskipun jumlahnya terbatas. Namun hanya 20\% tenaga guru yang menggunakan teknologi dalam kegiatan belajar mengajar pada materi IPA di sekolah. Guru kurang memanfaatkan teknologi karena minimnya prasarana seperti LCD yang tidak terpasang di setiap kelas, sehingga sebagian besar guru lebih memilih metode ceramah yang mengakibatkan pembelajaran hanya berpusat pada guru. Pada inovasi pembelajaran yang dilakukan guru hanya menggunakan metode diskusi dan praktik dalam proses pembelajaran IPA tanpa memanfaatkan teknologi secara optimal.

Paradigma pembelajaran yang tetap mempertahankan pola konvensional pada akhirnya akan sulit untuk meningkatkan literasi sains mahasiswa, karena pada pola konvensional, mahasiswa tidak dibiasakan untuk melibatkan seluruh kemampuan mereka dalam proses pemecahan masalah terkait materi yang mereka pelajari.

Materi penanganan dan pengolahan limbah merupakan salah satu materi IPA yang harus dikuasai oleh siswa. Hal ini dikarenakan penanganan dan pengolahan limbah merupakan materi yang berhubungan dengan lingkungan sekitar baik di sekolah atau rumah. Selain itu dengan mempelajari materi penanganan dan pengolahan limbah siswa dilatih untuk berpikir kritis dalam memecahkan permasalahan limbah di lingkungan siswa.

Salah satu permasalahan dalam kegiatan pembelajaran di kelas adalah kurang digunakannya strategi pembelajaran yang tepat dalam proses pembelajaran khususnya materi penanganan dan pengolahan limbah yang mana sudah semestinyalah mendudukkan siswa sebagai pusat perhatian utama, sedangkan guru berperan bagaimana menyediakan dan bagaimana memperkaya pengalaman belajar siswa, dan dengan pengalaman belajar yang mereka miliki, diharapkan siswa dapat mengambil tindakan dalam proses pemecahan masalah. Hal ini sejalan dengan paradigma yang diungkapkan oleh Aunurrahman (2010:15) bahwa "Telah terjadi perubahan paradigma dalam pembelajaran yang sebelumnya lebih menitikberatkan pada peran pendidik, dalam perjalanannya semakin bergeser pada pemberdayaan peserta didik, dimana peserta didik diberikan keleluasaan untuk berinisiatif dan berpartisipasi di dalam kegiatan belajar". Disini Aunurrahman menekankan bahwa dalam proses pembelajaran yang terpenting 
adalah bagaimana peserta didik dapat proaktif dan dilibatkan langsung dalam kegiatan pembelajaran. Berdasarkan pendapat tersebut salah satu strategi yang dianggap tepat untuk digunakan dalam proses pembelajaran IPA pada materi penanganan dan pengolahan limbah adalah pembelajaran berbasis konstruktivisme dimana guru berusaha mengkonstruk pengetahuan siswa selama proses pembelajaran berlangsung agar pembelajaran menjadi lebih bermakna.

Secara karakteristik materi penanganan dan pengolahan limbah merupakan materi yang bersifat konkret, dimana dalam proses pembelajarannya guru dapat memberikan pengalaman langsung kepada siswa dengan membawa mereka kepada lingkungan asli, tetapi apabila lokasi dan kondisi media asli dirasakan sulit untuk dijangkau serta menimbulkan biaya (Cost) yang besar, pembelajaran dapat menggunakan media pembelajaran berbasis TIK (Teknologi Informasi Komputer) sebagai media pengganti untuk mahasiswa mendapatkan pengalaman belajarnya. Ketersediaan media pembelajaran berbasis TIK (Teknologi Informasi Komputer) selama ini juga kurang dimanfaatkan oleh guru di dalam pembelajaran, dimana media seperti yang kita ketahui memiliki manfaat yang sangat baik untuk menjelaskan beberapa materi yang bersifat abstrak ke dalam bentuk konkret, begitupun sebaliknya tetapi dengan persyaratan-persyaratan tertentu yang menjadi keterbatasan dari media asli seperti kemudahan akses dan keterjangkauan.

Berbicara tentang media pembelajaran berbasis TIK (Teknologi Informasi Komputer) di dalam dunia pendidikan dapat dijadikan sebuah alternatif penyelenggaraan proses pembelajaran oleh guru di kelas. Menurut Sutrisno (2011:3) bahwa "TIK bukan hanya sebatas bagaimana mengoperasikan komputer saja, namun bagaimana menggunakan teknologi untuk berkolaborasi, berkomunikasi, melakukan penelitian, dan menyelesaikan berbagai persoalan dalam proses pembelajaran yang semakin kompleks dan berkembang secara dinamis". Definisi TIK (Teknologi Informasi Komputer) menurut Tinio (2002:4) adalah "ICTs stand for information and communication technologies and are defined, for the purposes of this primer, as a "diverse set of technological tools and resources used to communicate, and to create, dis-seminate, store, and manage information." These technologies include computers, the Internet, broad-casting technologies (radio and television), telephony and computer".

Menurut kedua definisi diatas, dapat dijelaskan bahwa keberadaan teknologi berbasis TIK (Teknologi Informasi Komputer) sebagai sekumpulan alat elektronik dan sumber daya yang digunakan untuk berkomunikasi, menciptakan, menyebarkan, menyimpan, dan mengelola informasi dalam pengelolaan pendidikan harus dimaknai sebagai upaya untuk meningkatkan efektivitas dan efesiensi dimana teknologi itu sendiri tidak dapat dipisahkan dari masalah, sebab penggunaan teknologi dalam pembelajaran lahir dan dikembangkan untuk memecahkan permasalahan yang dihadapi oleh guru dan siswa yang akan menyebabkan perubahan terhadap tuntutan penyelenggaraan pendidikan dalam berbagai aspek.Pemerintah pada saat ini sangat mendukung penggunaan TIK tersebut dalam pembelajaran demi meningkatkan pembangunan nasional melalui bidang pendidikan yang terintegrasi dengan penggunaan teknologi berbasis TIK dalam pengelolaan pendidikan, pemerintah telah menetapkan kebijakan melalui Inpres No 6/2001 tentang telematika yang diharapkan menjadi bagian penting dari sistem pendidikan sehingga kurikulum sekolah secara bertahap disesuaikan dengan kebijakan tersebut. Keppres No 20/2006 tentang terwujudnya masyarakat indonesia berbasis pengetahuan pada tahun 2025 melalui pendayagunaan dan optimalisasi TIK (Teknologi Informasi Komputer). Sementara itu, Kepmendiknas No 50/P/2007, salah satunya menyatakan bahwa 50\% SMA/MA/SMK menerapkan pembelajaran berbasis TIK pada tahun 2009. (Sutrisno, 2011:7). 
Menurut Alessi dan Trollip (dalam Sutrisno, 2011:3) "Pembelajaran berbasis TIK memiliki banyak keunggulan. Salah satunya, keunggulan itu berupa penggunaan waktu yang digunakan menjadi lebih efektif, bahan materi pelajaran menjadi lebih mudah diakses, menarik, dan murah biayanya". Penjelasan dari Alessi dan Trollip dapat dimaknai bahwa digunakannya media pembelajaran dapat memberikan beberapa keuntungan atau manfaat, selain penggunaan media dapat mengarah kepada penggunaan waktu secara efektif dan efesien, media pembelajaran juga dapat menjadi daya tarik tersendiri untuk memotivasi peserta didik dalam belajar, dan dari sisi ekonomi media pembelajaran berbasis teknologi TIK lebih terjangkau untuk diberdayakan.

Pemahaman guru terkait penguasaan teknologi dalam pembelajaran juga menjadi pengetahuan yang harus dimiliki guru untuk melaksanakan instruksi konstruktivisme, dengan bantuan teknologi yang disebut sebagai konstruktivisme yang berorientasi teknologi serta merelevansikannya dengan pengetahuan pedagogik serta konten materi. Saat ini tidak ada survei yang tersedia untuk memahami persepsi guru dalam aspek ini. Oleh karena itu, perlu digunakannya sebuah kerangka kerja yang dapat memberikan arah baru bagi guru dalam memecahkan masalah terkait dengan mengintegrasikan teknologi ke dalam kegiatan belajar mengajar di ruang kelas agar kesenjangan pengetahuan dalam hal integrasi teknologi pada pembelajaran konstruktivis dapat dipahami dengan baik, solusi yang dapat digunakan adalah dengan menggunakan sebuah kerangka kerja TPCK (Technological Pedagogical Content Knowledge), kerangka kerja ini yang dapat memberikan arah dalam pembelajaran bermakna yang berorientasi pada TIK.

Menurut Cox and Graham (2009); Mishra and Koehler (2006) (dalam Puspitarini, Sunaryo, dan Suryani, 2013:1) Technological Pedagogical Content Knowledge (TPCK) adalah pengetahuan tentang bagaimana memfasilitasi pembelajaran siswa dari konten tertentu melalui pendekatan pedagogik dan teknologi.

Dalam pembelajaran dengan kerangka kerja TPCK, menurut Sutrisno (2011:94) terdapat penggabungan tiga unsur pengetahuan, ilmu pengajaran dan integrasi teknologi sehingga siswa dapat menyelesaikan tugas dengan baik dan menuntaskan permasalahan baru yang muncul dalam proses menyelesaikan tugas tersebut. Keunggulan TPCK dibandingkan konsep lainnya adalah menyusun instruksi pembelajaran dengan mengutamakan pedagogis atau pengalaman siswa yang diintegrasikan dengan Teknologi Informasi dan Komunikasi (TIK) sehingga memberi sumbangan yang amat besar terhadap perubahan dan paradigma pembelajaran.

Sejalan dengan pendapat Harris et al (dalam Putriani dan Sarwi (2014:38) bahwa perangkat TPCK yang dikembangkan berfungsi untuk meningkatkan pemahaman konsep dan menumbuhkan keaktifan belajar siswa. Dalam penelitian ini pemilihan alat bantu TIK disesuaikan dengan tujuan pembelajaran dan materi pembelajarannya agar siswa mendapatkan pengalaman belajar yang lebih baik untuk mengkonstruksi pengetahuannya sehingga siswa mampu mendapatkan sendiri konsep dari materi yang dipelajarinya.

Pembelajaran berbasis konstruktivisme dengan kerangka kerja Technological Pedagogical Content Knowledge (TPCK) merupakan suatu pembelajaran yang melibatkan sifat pengetahuan yang diperlukan oleh guru untuk mengintegrasikan teknologi dalam pengajaran. TPCK dianggap sebagai kerangka kerja berpotensi yang dapat memberikan arah baru bagi guru dalam memecahkan masalah terkait dengan mengintegrasikan TIK ke dalam kegiatan belajar mengajar di ruang kelas (Hewitt dalam Puspitarini, Sunaryo, dan Suryani, 2013:1). Pembelajaran dengan kerangka kerja TPCK dilaksanakan dengan maksud agar siswa SMK dapat lebih membiasakan diri melakukan simulasi secara interaktif dengan menggunakan media pembelajaran berbasis animasi secara langsung dalam rangka pemahaman konsep serta memecahkan suatu masalah. 
Selain dari faktor-faktor eksternal, prestasi belajar IPA juga dipengaruhi oleh faktor internal siswa. Faktor internal dari dalam diri siswa salah satu yang berpengaruh adalah gaya belajar siswa. Menurut DePorter and Hernacki (2009:112-113) gaya belajar adalah kombinasi dari bagaimana seseorang menyerap dan kemudian mengatur serta mengolah informasi. Proses belajar tidak lepas dari faktor seorang siswa dapat menyerap dan mengatur serta mengolah informasi yaitu bagaimana siswa dapat menyerap informasi yang disampaikan dengan mudah dan bagaimana siswa mengatur dan mengolah informasi yang disampaikan tersebut di dalam otak atau dominasi otak, maka jika seseorang sudah akrab dengan gaya belajarnya ia dapat mengambil langkah-langkah penting untuk membantu dirinya belajar dengan cepat dan mudah.

Gaya belajar (Learning Styles) dianggap memiliki peranan penting dalam proses kegiatan belajar mengajar. Siswa yang kerap dipaksa belajar dengan cara-cara yang kurang cocok dan berkenan bagi mereka tidak menutup kemungkinan akan menghambat proses belajarnya terutama dalam hal berkonsentrasi saat menyerap informasi yang diberikan. Pada akhirnya hal tersebut juga akan berpengaruh pada hasil belajar yang belum maksimal sebagaimana yang diharapkan.

Mengetahui keberagaman gaya belajar siswa akan membantu guru untuk dapat mendekati semua siswa hanya dengan menyampaikan informasi dengan gaya yang berbeda-beda yang disesuaikan dengan gaya belajar siswa. Setiap siswa mempunyai gaya belajar yang berbeda-beda sesuai kemampuan untuk mempermudah diri mereka sendiri dalam memahami suatu materi yang diberikan. Gaya belajar sendiri melibatkan kemampuan intern siswa meliputi gaya belajar visual dimana panca indera berperan didalamnya kemampuan untuk melihat, meraba dan membau. Selain itu gaya belajar auditif mengandalkan kesuksesan belajarnya melalui telinga (alat pendengaran). Untuk itu sebaiknya harus memperhatikan siswanya hingga ke alat pendengarannya, karena akan sia-sia guru yang menerangkan kepada siswa yang memiliki pendengaran yang kurang walaupun guru tersebut menerangkan dengan lantang, jelas dan dengan intonasi yang tepat. Berikutnya gaya belajar kinestetik dimana siswa belajar melalui gerak dan sentuhan. Keberagaman gaya belajar siswa di SMK belum diperhatikan oleh guru dalam proses pembelajaran.

Berdasarkan uraian di atas, maka pada pembelajaran IPA, khususnya pada materi penanganan dan pengolahan limbah digunakan pembelajaran berbasis konstruktivisme menggunakan media animasi dengan kerangka kerja TPCK (Technological Pedagogical Content Knowledge) dan gaya belajar siswa. Perumusan masalah dari penelitian ini adalah; 1) Bagaimanakah profil gaya belajar siswa kelas XI SMK 1 Dedai?; 2) Apakah terdapat pengaruh pembelajaran berbasis konstruktivisme menggunakan media animasi terhadap prestasi belajar siswa pada materi penanganan dan pengolahan limbah?; 3) Apakah terdapat pengaruh gaya belajar visual dan kinestetik terhadap prestasi belajar siswa pada materi penanganan dan pengolahan limbah ?; dan 4) Apakah terdapat pengaruh pengunaan media animasi dan gaya belajar terhadap prestasi belajar siswa pada materi penanganan dan pengolahan limbah?. Adapun tujuan penelitian ini adalah untuk mengetahui; 1) Profil gaya belajar siswa; 2) Pengaruh pembelajaran berbasis konstruktivisme menggunakan media animasi terhadap prestasi belajar siswa pada materi penanganan dan pengolahan limbah; 3) Pengaruh gaya belajar visual dan kinestetik terhadap prestasi belajar siswa pada materi penanganan dan pengolahan limbah; 4) pengaruh pengunaan media animasi dan gaya belajar terhadap prestasi belajar siswa pada materi penanganan dan pengolahan limbah. Berdasarkan tujuan penelitian, hipotesis yang akan dihasilkan dalam penelitian ini adalah; 1) Terdapat pengaruh pembelajaran berbasis konstruktivisme menggunakan media animasi terhadap prestasi belajar siswa pada materi penanganan dan pengolahan limbah; 2) Terdapat pengaruh gaya belajar visual dan 
kinestetik terhadap prestasi belajar siswa pada materi penanganan dan pengolahan limbah; dan 3) Terdapat pengaruh pengunaan media animasi dan gaya belajar terhadap prestasi belajar siswa pada materi penanganan dan pengolahan limbah.

\section{METODE}

Penelitian ini dilakukan di SMK 1 Dedai Kabupaten Sintang Provinsi Kalimantan Barat. Penelitian ini menggunakan metode eksperimen dengan rancangan penelitian menggunakan desain true eksperimen dua kelompok yakni kelas eksperimen dan kelas kontrol.

Dalam penelitian ini terdapat dua variabel yakni; 1) Variabel bebas yakni pembelajaran berbasis konstruktivisme menggunakan media animasi dan gaya belajar; dan 2) Variabel terikat adalah prestasi belajar siswa.

Pengambilan sampel dilakukan secara acak menggunakan teknik simple random sampling dari 4 (empat) kelas yang digunakan sebagai populasi dari kelas XI. Sampel yang digunakan sebanyak 35 siswa yang berada dalam satu kelas eksperimen dan 35 siswa berada pada kelas kontrol. Kelas eksperimen diberikan perlakuan pembelajaran berbasis konstruktivisme menggunakan media animasi, sedangkan pada kelas kontrol diberikan perlakuan menggunakan metode konvensional.

Teknik dan alat pengumpulan data dalam penelitian ini menggunakan; 1) teknik pengukuran dengan alat pengumpul data berupa tes hasil belajar siswa untuk melihat prestasi belajar siswa dalam ranah kognitif; 2) teknik komunikasi tidak langsung dengan alat pengumpul data berupa angket untuk melihat gaya belajar siswa; dan 3) teknik observasi langsung dengan alat pengumpul data lembar observasi untuk melihat hasil belajar siswa pada ranah afektif dan psikomotor. Instrumen pelaksanaan pembelajaran pada penelitian ini berupa silabus, Rencana Pelaksanaan Pembelajaran (RPP), serta media animasi.

Uji normalitas menggunakan adalah uji Shapiro-Wilk, dan uji homogenitas menggunakan Levene Test dengan perhitungan menggunakan software SPSS 21, kemudian pengujian hipotesis pada penelitian ini menggunakan uji Anava yakni pengujian yang dilakukan secara serentak oleh semua variabel bebas dengan bantuan software SPSS 21.

HASIL DAN PEMBAHASAN

Deskripsi data gaya belajar siswa disajikan pada Tabel 2 di bawah ini.

Tabel 2. Diskripsi Data Gaya Belajar Siswa

\begin{tabular}{ccccccc}
\hline Gaya & \multicolumn{3}{c}{ Kelas Eksperimen } & \multicolumn{3}{c}{ Kelas Kontrol } \\
Belajar & Mean & $\mathrm{F}$ & $(\%)$ & Mean & $\mathrm{F}$ & $(\%)$ \\
\hline \hline Visual & 69,35 & 7 & 19,44 & 68,43 & 13 & 36,11 \\
Kinestetik & 64,77 & 28 & 80,56 & 66,59 & 22 & 63,89 \\
Jumlah & & 35 & 100 & & 35 & 100 \\
\hline
\end{tabular}

Dari tabel 2 dapat di lihat bahwa kelas eksperimen mempunyai nilai rerata 69,35 untuk gaya belajar visual, sedangkan gaya belajar kinestetik 65,77 . Jumlah siswa yang mempunyai gaya belajar visual 7 siswa atau 19,44\% dan 28 siswa atau 80,56\% yang mempunyai gaya belajar kinestetik. Pada kelas kontrol mempunyai nilai rerata 68,43 untuk gaya belajar visual, sedangkan gaya belajar kinestetik 66,59. Jumlah siswa yang mempunyai gaya belajar visual 13 siswa atau 36,11\% dan 22 siswa atau 63,89\% yang mempunyai gaya belajar kinestetik, dari data pada kelas eksperimen dan kelas kontrol 
gaya belajar kinestetik lebih banyak dimiliki oleh siswa dibandingkan gaya belajar visual hal ini dikarenakan memang kecenderungan siswa SMK mempunyai gaya belajar kinestetik karena lebih banyak melakukan praktik daripada mendengarkan penyampaian materi di dalam kelas.

Berdasarkan data yang diperoleh pada hasil penelitian, berikut pada Tabel 3 disajikan deskripsi data prestasi belajar siswa.

Tabel 3. Deskripsi Data Prestasi Belajar Siswa

\begin{tabular}{lcccc}
\hline & Jumlah & \multicolumn{3}{c}{ Prestasi Belajar } \\
\cline { 3 - 5 } \multicolumn{1}{c}{ Kelas } & Data & Kog & Afektif & Psikomotor \\
\hline \hline Eksperimen & 35 & 74.28 & 70.04 & 73.24 \\
Kontrol & 35 & 68.80 & 69.34 & 67.78 \\
\hline
\end{tabular}

Rerata prestasi belajar siswa cenderung bervariasi, pada kelas eksperimen dengan penggunaan media animasi dengan jumlah siswa 35 memiliki rerata prestasi belajar kognitif 74,28 , rerata prestasi belajar afektif 70,04 dan rerata prestasi belajar psikomotor 73,24 , sedangkan rerata prestasi belajar siswa pada kelas kontrol dengan metode ceramah dengan jumlah siswa 35 memiliki rerata prestasi belajar kognitif 68.80, prestasi belajar afektif 69.34 dan prestasi belajar psikomotor 67.78. Berdasarkan data tersebut menunjukkan bahwa nilai kognitif, afektif dan psikomotor pada kelas eksperimen lebih baik dari kelas kontrol.

Data yang diperoleh tersebut kemudian diolah menggunakan analisis statistik anava. Rangkuman hasil uji statistik disajikan pada tabel 4, tabel 5 dan tabel 6 dibawah ini.

Tabel 4.Rangkuman Anava Prestasi Belajar Kognitif

\begin{tabular}{lllc}
\hline \multicolumn{1}{c}{ Variabel Uji } & df & P-Value & Hipotesis \\
\hline Media Animasi & 1 & 0,023 & Ho2 Diterima \\
Gaya Belajar & 1 & 0,005 & Ho2 Diterima \\
Media & 1 & 0,030 & Ho2 Diterima \\
*Gaya Belajar & & & \\
\hline
\end{tabular}

Tabel 5. Rangkuman Anava Prestasi Belajar Afektif

\begin{tabular}{lccc}
\hline \multicolumn{1}{c}{ Variabel Uji } & df & P-Value & Hipotesis \\
\hline Media Animasi & 1 & 0,000 & Ho2 Diterima \\
Gaya Belajar & 1 & 0,065 & Ho1 Diterima \\
Media & 1 & 0,048 & Ho2 Diterima \\
*Gaya Belajar & & & \\
\hline
\end{tabular}

Tabel 6. Rangkuman Anava Prestasi Belajar Psikomotor

\begin{tabular}{lccc}
\hline \multicolumn{1}{c}{ Variabel Uji } & df & P-Value & Hipotesis \\
\hline Media Animasi & 1 & 0,011 & Ho2 Diterima \\
Gaya Belajar & 1 & 0,008 & Ho2 Diterima \\
Media & 1 & 0,002 & Ho2 Diterima \\
*Gaya Belajar & & & \\
\hline
\end{tabular}

a. Hipotesis pertama

Hasil uji statistik anava pada ranah prestasi belajar kognitif dengan menggunakan media animasi didapatkan harga p 0,023, sehingga $p$-value $<0,05$. Sedangkan Hasil uji 
statistik anava pada ranah prestasi belajar afektif dengan menggunakan media animasi didapatkan harga $\mathrm{p} 0,000$, sehingga $p$-value $<0,05$, dan hasil uji statistik anava pada ranah prestasi belajar psikomotor dengan menggunakan media animasi didapatkan harga p 0,011, sehingga $p$-value $<0,05$. Berdasarkan hasil uji tersebut terlihat bahwa untuk ketiga ranah prestasi belajar mendapatkan hasil dimana nilai $p$-value $<0,05$, dengan hipotesis Ho2 diterima. Dapat disimpulkan bahwa hipotesis nol ditolak dan hipotesis alternatif diterima, maka terdapat pengaruh pembelajaran berbasis konstruktivisme menggunakan media animasi terhadap prestasi belajar siswa pada materi penanganan dan pengolahan limbah. Berdasarkan kegiatan proses belajar mengajar, siswa pada kelas eksperimen yang menggunakan media animasi mempunyai lebih banyak kesempatan mengeksplorasi kemampuan mereka dengan bekerjasama dalam kelompok maupun individu, serta lebih memahami dalam mengerjakan soal-soal latihan karena semua kegiatan dilakukan dengan melakukan simulasi secara interaktif melalui perangkat TIK. Terjadinya pengaruh prestasi belajar dengan menggunakan media pembelajaran berbasis animasi, sejalan dengan penelitian yang dilakukan oleh Huppert (dalam Becta, 2010) yang berjudul "Computer Simulation in High Scholl: Student Cognitive Stages, Science Process Skil and Academic Achievement in Microbiology". Hasil penelitian tersebut menunjukkan bahwa prestasi belajar siswa dengan menggunakan komputer simulasi lebih baik dibandingkan dengan yang tidak menggunakan. Penelitian yang dilakukan oleh Potyrala (2002:15) yang berjudul "ICT Tools in Biology Education", hasil penelitian tersebut menunjukkan bahwa teknologi informasi memfasilitasi tujuan pendidikan dengan mengaktifkan siswa dalam proses kognitif.

b. Hipotesis kedua

Hasil uji statistik anava pada ranah prestasi belajar kognitif dengan tinjauan terhadap gaya belajar didapatkan harga p 0,005, sehingga $p$-value $<0,05$. Sedangkan Hasil uji statistik anava pada ranah prestasi belajar afektif tinjauan terhadap gaya belajar didapatkan harga p 0,065, sehingga $p$-value $>0,05$, dan hasil uji statistik anava pada ranah prestasi belajar psikomotor dengan menggunakan media animasi didapatkan harga p 0,008, sehingga $p$-value $<0,05$. Berdasarkan hasil uji tersebut terlihat bahwa untuk ketiga ranah prestasi belajar mendapatkan hasil pada ranah kognitif dan psikomotor dimana nilai $p$-value $<0,05$, sedangkan pada ranah afektif nilai $p$-value $>0,05$ dengan hipotesis Ho1 diterima. Dapat disimpulkan bahwa hipotesis nol diterima dan hipotesis alternatif ditolak, maka tidak terdapat pengaruh gaya belajar terhadap prestasi belajar siswa pada materi penanganan dan pengolahan limbah. Hal ini sejalan dengan penelitian yang dilakukan oleh Supi Iswari (2010) dengan judul "Pembelajaran Biologi Metode Inkuiri Terbimbing Menggunakan Lab Riil dan Lab Virtuil Ditinjau dari Sikap Ilmiah dan Gaya Belajar Siswa, menunjukkan bahwa gaya belajar tidak berpengaruh di dalam peningkatan hasil belajar biologi siswa. Hal ini dikarenakan di bahwa siswa sudah sangat mengenal akan gaya belajar mereka sendiri dimana pada siswa SMK diperoleh bahwa siswa dengan gaya belajar kinestetik lebih banyak dibandingkan siswa dengan gaya belajar visual. Karakteristik siswa dengan gaya belajar kinestetik di dalam pembelajarannya, pendekatan yang mungkin bisa dilakukan adalah belajar berdasarkan atau melampaui pengalaman dengan menggunakan berbagai model atau peraga, bekerja di laboratorium atau bermain sambil belajar. Cara lain yang juga bisa digunakan secara tetap membuat jeda di tengah waktu belajar. Tak jarang, orang yang cenderung memiliki karakter kinestetik learners juga akan lebih mudah menyerap dan memahami informasi dengan cara menjiplak gambar atau kata untuk belajar mengucapkannya atau memahami fakta. Penggunaan komputer bagi orang kinestetik akan sangat membantu. Karena, dengan komputer ia bisa terlibat aktif dalam melakukan touch (sentuhan, sekaligus menyerap informasi dalam bentuk gambar dan tulisan. Selain itu, agar belajar menjadi 
lebih efektif dan berarti, orang dengan karakter kinestetik disarankan untuk menguji memori ingatan dengan cara melihat langsung fakta di lapangan (Uno, 2010:182).

c. Hipotesis ketiga

Hasil uji statistik anava pada ranah prestasi belajar kognitif dengan menggunakan media animasi dan gaya belajar didapatkan harga p 0,030, sehingga p-value < 0,05. Sedangkan Hasil uji statistik anava pada ranah prestasi belajar afektif dengan menggunakan media animasi dan gaya belajar didapatkan harga $\mathrm{p} 0,048$, sehingga $p$ value $<0,05$, dan hasil uji statistik anava pada ranah prestasi belajar psikomotor dengan menggunakan media animasi dan gaya belajar didapatkan harga p 0,002, sehingga $p$ value $<0,05$. Berdasarkan hasil uji tersebut terlihat bahwa untuk ketiga ranah prestasi belajar mendapatkan hasil dimana nilai $p$-value $<0,05$, dengan hipotesis $\mathrm{Ho} 2$ diterima. Dapat disimpulkan bahwa hipotesis nol ditolak dan hipotesis alternatif diterima, maka terdapat pengaruh pembelajaran menggunakan media animasi dan gaya belajar terhadap prestasi belajar siswa pada materi penanganan dan pengolahan limbah. Berdasarkan hasil di atas, dapat disimpulkan bahwa siswa mendapatkan pengalaman belajarnya secara langsung dari proses transformasi dan simulasi dari media, hal tersebut merujuk pada pendapat Galarneau (dalam Sutrisno, 2011: 4) yang menjelaskan bahwa "Penerapan TIK di berbagai sekolah dan institusi pendidikan telah dilaksanakan dengan pencapaian hasil belajar siswa yang cukup membanggakan". Penjelasan Galernau di atas, dapat diartikan sebagai pola pembelajaran satu arah yang terpusat kepada pendidik (Teacher Center) diakui mempunyai strategi yang kaku dan formal, akibatnya kreativitas, aktivitas dan kemauan belajar secara mandiri siswa tidak tumbuh sesuai dengan yang diharapkan bahkan cenderung bersifat pasif.

Siswa yang dapat dengan cepat beradaptasi terhadap proses transformasi media akan menimbulkan gaya kognitif, yang mana merupakan salah satu variabel kondisi belajar yang menjadi salah satu bahan pertimbangan dalam mengkonsep materi pembelajaran (Bruce Joyce dalam Allyn and Bacon, 1992, dalam Hamzah B.Uno, 2007:185). Hal ini tentu saja sangat menguntungkan sekali bagi guru karena siswa sudah mendapatkan pengetahuan tentang gaya kognitif yang dibutuhkan untuk mengkonsep atau memodifikasi materi pembelajaran, tujuan pembelajaran, sehingga hasil belajar siswa dapat dicapai semaksimal mungkin.

\section{PENUTUP}

\section{Simpulan}

Sesuai dengan tujuan penelitian, hasil penelitian, dan pembahasan pada bab sebelumnya, maka dalam penelitian ini dapat disimpulkan sebagai berikut:

1. Terdapat profil gaya belajar siswa kelas XI SMK 1 Dedai.

2. Terdapat pengaruh pembelajaran berbasis konstruktivisme menggunakan media animasi terhadap prestasi belajar siswa.

3. Tidak terdapat pengaruh gaya belajar terhadap prestasi belajar siswa

4. Terdapat pengaruh penggunaan media animasi dan gaya belajar terhadap prestasi belajar siswa.

\section{Rekomendasi}

Berdasarkan kesimpulan dan implikasi dari penelitian maka penulis mengajukan saran-saran sebagai berikut:

1. Kepada guru

a. Penggunaan strategi pembelajaran berbasis konstruktivisme menggunakan media animasi telah terbukti dapat meningkatkan hasil prestasi belajar siswa 
baik kognitif, afektif dan psikomotor, oleh karenanya disarankan untuk digunakan dalam proses pembelajaran di SMK 1 Dedai.

b. Penerapan strategi pembelajaran berbasis konstruktivisme menggunakan media animasi ini merupakan proses pembelajaran yang kompleks dimana memerlukan bantuan observer, maka disarankan bagi guru untuk melibatkan guru lain membentuk team teaching.

c. Guru diharapkan untuk dapat melihat factor-faktor internal lainnya dari siswa selain gaya belajar yang dapat mempengaruhi prestasi belajar siswa.

d. Guru sebaiknya melakukan uji coba terlebih dahulu terhadap alat yang akan digunakan sebagai media pembelajaran sesuai dengan kerangka kerja TPCK agar pembelajaran berjalan sesuai dengan karakteristik konten materi.

2. Kepada peneliti

a. Hasil penelitian ini dapat digunakan sebagai acuan untuk penelitian yang sejenis dengan kompetensi dasar yang berbeda.

b. Penelitian ini dapat dikembangkan dengan penambahan variabel lain.

\section{DAFTAR PUSTAKA}

Aunurrahman. 2009. Belajar dan Pembelajaran. Bandung: Alfabeta.

Becta. 2010. Educational research on the use of ICT in science teaching - a selection of abstracts and further sources. USA

De Porter,Bobbi \& Hernacki,Mike. 2009. Quantum Learning: Membiasakan Belajar Nyaman dan Menyenangkan. Bandung: Kaifa.

Uno, Hamzah B. 2007. Teori Motivasi dan Pengukurannya Analisis di Bidang Pendidikan. Jakarta: Bumi Aksara.

Uno, Hamzah B. 2010. Perencanaan Pembelajaran. Jakarta: Bumi Aksara.

Langeveld, 1971. Beknopte Theoretische Pedagogiek. Groningen: Wolters (Noordhof).

PISA. 2012. What Student Know and Can Do; Student Performance in Reading, Mathematics and Science. www.oecd.org/pisa/.15 Juni 2014.

Puspitarini, Sunaryo, dan Suryani. 2013. Pemodelan TPACK berbasis Teknologi Informasi dan Komunikasi dengan pendekatan Structural Equation Modelling (SEM). Prosiding Seminar Nasional Manajemen Teknologi XVIII. Program Studi Magister Manajemen Teknologi, Institut Teknologi Surabaya.

Putriani dan Sarwi. 2014. Implementasi Strategi TPACK dengan media simulasi berbasis inkuiri terbimbing pada konsep getaran dan gelombang. Unnes Phisycs Education Journal. 3(2), 34-41.

Potyrala, K. 2002. ICT Tools in Biology Education. Department of Biology Didactics, Institute of Biology, Pedagogical University of Cracow. POLAND.

Suciati Sudarisman. 2010. Membangun Karakter Peserta Didik Melalui Pembelajaran Biologi Berbasis Keterampilan Proses. Prosiding Seminar Nasional VII Pendidikan Biologi. FKIP. Universitas Negeri Surakarta.

Supi Iswari. 2010. Pembelajaran Biologi Metode Inkuiri Terbimbing Menggunakan Lab Riil dan Lab Virtuil Ditinjau dari Sikap Ilmiah dan Gaya Belajar Siswa. Thesis: UNS Surakarta

Sutrisno. 2011. Pengantar Pembelajaran Inovatif. Jakarta: Gaung Persada Press.

TIMSS. 2011. Mathematics and Science Literacy, Advanced Mathematics and Physics. IEA: http://timss:bc.edu/. diakses 15 Juni 2014.

Tinio.V.L. 2002. ICT in Education. United Nations Development Programme Bureau for development policy, New York.

Uno H.B. 2010. Orientasi Baru Dalam Psikologi Pembelajaran. Jakarta: PT. Bumi Aksara. 